\title{
The Empirical Study of Performance Evaluation on the Specialized Cooperative Organizations of Farmers in Sichuan by AHP
}

\author{
Dongmei Li (Corresponding author) \\ College of Economics Management, Sichuan Agricultural University \\ No.211, Hui Ming Road, Wen Jiang District, Chengdu City 611130, Sichuan, China \\ E-mail: cndldm@163.com \\ Man Tian \\ College of Economics Management, Sichuan Agricultural University \\ No.211, Hui Ming Road, Wen Jiang District, Chengdu 611130, Sichuan, China \\ E-mail: 676045038@qq.com
}

Received: December 17, $2011 \quad$ Accepted: February 6, 2012 Published: March 1, 2012

doi:10.5539/jms.v2n1p200 URL: http://dx.doi.org/10.5539/jms.v2n1p200

\begin{abstract}
With the implementation of specialized cooperative organizations of farmers Law of $P$. R. China in 2007, the specialized cooperative organizations of farmers in China has entered a stage of quick development. But beyond the increasing quantity of cooperatives, whether such development is sustainable or not has become a question that caught attention from both government and academics. This thesis took 142 specialized cooperative organizations of farmers in Sichuan province as object, by using AHP from 5 aspects including governance mechanism, income, development potential, social influence and ecology influence, finally concluded the study on evaluation of performance. The result of the evaluation shows that competitiveness of farmer's cooperatives in Sichuan is still rather weak, operation management is not yet standardized, integral development is inconsistent and development potential of which require further improve.
\end{abstract}

Keywords: Specialized cooperative organizations of farmers, Performance, AHP

\section{Introduction}

With the implementation of specialized cooperative organizations of farmers Law of P. R. China in 2007, farmers' cooperatives in China has entered a stage of quick development. According to statistics from Sichuan Administration For Industry \& Commerce, in late June, 2011, the quantity of registered Farmers' Cooperatives in Sichuan was 17016 ranking $9^{\text {th }}$ in whole country, the member of which reached 261.2 thousand, the capital input was 21.091 billion, capital per cooperative was 1.2395 million. Farmer's cooperative conduct business mainly traditional farm production like fruit, vegetable, Chinese medical crop, edible mushroom, flowers and trees and animal husbandry like livestock raising, bee-keeping, aquaculture, etc. Meanwhile with its expansion, whether such development is sustainable or not has become a concern for both government and academics and the study on performance and potential of cooperative has become a hot spot in current agricultural economy world. Until now, scholars made their effort from evaluation of organization structure and its operation (Keding Pan, 2010; Zuhui Huang, 2010), evaluation of system of Farmer's cooperative (Yitan Yang, 2005), evaluation of management of Farmer's cooperative (Jingwei Hu, 2010).

However, most studies were for comparatively better-off area in middle and east of China, rare could be found for southwest. Therefore, this thesis is aimed to understanding current state of Sichuan's economy and farmer's cooperatives. A evaluation system was made so each cooperative could check each self according to each performance indicator in order to understand its situation, existing problem and gap in between. Also, performance evaluation is of significant meaning in new situation finding out standardized development goal, direction and policy making. 


\section{Performance evaluation methods literature review}

\subsection{Overview of performance evaluation methods}

"Performance" is derived from western management and one of its definition is accomplishment including individual and organizational. Organizational performance is completed based on individual one but individual accomplishment doesn't necessarily create organizational performance. Evaluation of performance could help finding out the outcome of one activity, direct output and service of one activity or the outcome of such products and service (Win Anley, 2001). Definition of farmers' cooperatives according to specialized cooperative organizations of farmers Law of P. R. China (2007), are mutual-help economic organizations joined voluntarily and managed in a democratic manner by the producers and operators of the same kind of farm products or by the providers or users of services for the same kind of agricultural production and operation. Usual Methods adopted for empirical study is Fuzzy Comprehensive Evaluation (FCE), Expert's value assignment method, AHP and Factor Analysis etc. Jiarong Zhao (2009) based on survey from 22 sample cooperatives, by using AHP, made in-depth analysis on organization system and performance of Liuyang farmer's cooperatives. Bin Liu (2009) by using AHP based on 22 cooperatives in Jiangxi province concluded the cooperative development potential is not strong, social influence to be raised. Fang Wang (2011) by using AHP made empirical study on performance of banana cooperatives. AHP has been widely applied in performance evaluation and based from the efforts before. This thesis also adopted AHP.

\subsection{AHP literature review}

A.L. Saaty proposed AHP at 70's in American. Which is a qualitative and quantitative decision analysis method will make complex system decision modeling and quantification.

For performance evaluation on employees of the enterprise, institution staff, national public servant, XiChuan Huang (1993) using AHP evaluated the performance of science and technology personnel from scientific research output (such as paper, results, etc.). XiaoXu Lu (2011) used AHP to determine the index weight, and performance evaluation on compulsory education teacher, then formulate scheme about performance salary allocation of compulsory education teacher. Lei Li (2011) used AHP to study performance appraisal system on the public unit high knowledge staff.

For Performance evaluation on social benefits or economic benefit, ChunYan Ren (2011) using AHP analyzed the agricultural economic survey data from 2001 to 2008 about zhifanggou watershed to evaluation agricultural ecological economic system effectiveness. Li Gui (2011) used AHP builds rural community health service satisfaction assessment index and evaluation model based on the data of hebei province. Chun LuoXiao (2011) by using AHP constructed the performance evaluation index system on third party logistics customer service.

For Performance evaluation on enterprise or a community, ChenJia Li (2011) used AHP to evaluate main ability and the order of comprehensive strength by using 14 listed bank data in 2008. MingCong Gong (2011) using AHP established performance evaluation system on financial expenditure in GuiLin city from business, financial and performance. XiaoWei Li (2011) constructed comprehensive performance evaluation index system on meat enterprise and established AHP model.

For Evaluation on the policy or decision making, HongLi Zhao (1993) using the ahp decision analyzed the land comprehensive development planning from the land and resources characteristics of chaidamu areas. YongGang Nie (2011) in order to improve the enterprise management level of the decision constructed the enterprise environment cost decision model by AHP. XuWu (2011) with AHP established the Tibet plateau basin ecology decision evaluation model.

In addition to the above comment, AHP is also used for competitiveness evaluation (Mingxia Qian, ZhongKun Jin, SongLiu, 2011) and the evaluation of risk (XueLiang Wang 2011) etc.

\section{Hypothesis and variables}

\subsection{Hypothesis}

Performance evaluation of farmer's cooperative is rather new in theoretical research of which systematic appraise has not been given until now. Also, there is no standard indicator system for evaluation. Liping Wang (2008) come to the task by analyzing economic function, social function and ecological function of cooperative. Zhejiang agricultural research (2008), Xuchu Xu (2009) \& Xuchu Xu (2010), Kequn Cheng (2011) try to solving the problem started from its definition to evaluate its performance from behavioral indicator and productive indicator.

Hypothesis is that performance of farmer's cooperative is the aggregation of its inner management, development 
potential, social function and ecology function. Therefore, this thesis made study on five aspects, organization income, development potential, social impact and ecological impact. Among them, management mechanism reflects inner governance ability. Development potential shows its future value, organization income, social impact and ecological demonstrates its value respectively in economy, society and eco-system.

\subsection{Variables}

This thesis designed 17 indicators according to the 5 aspects, calculation of which had drew lessons from recognition criteria for agriculture industrialization leading enterprise in Sichuan province according to Interim Provisions for administration of agriculture industrialization leading enterprise in Sichuan. The calculation was made from 5 aspects for the cooperatives.

As to management mechanism, Jingwei Hu (2010) singled it out to performance evaluation. Bin Liu (2009) blended it into whole evaluation system. This thesis holds the point that management mechanism is being an important indicator that plays a role as a mirror of inner performance. It covers many questions like the number of member, its hierarchy, whether are personnel designated to monitor the quality of farmer's business. As to organization income, Kequn Cheng (2011) added member's satisfaction in describing organization's management, the number of training for cooperative member and mu of standardized production area. I think organization income reflects economic performance which comprises tangible and intangible one. Tangible income of cooperative includes annual gains, profit and loss and ratio between agricultural food sales volume from cooperative members and total sales volume. Profit and loss is an average value within 2 years. Intangible income includes members' satisfaction and brand awareness. For development potential, Fang Wang (2011) defined it by number of high quality staff and number of certified products. I think development potential accounts for future development of cooperative. $\mathrm{Mu}$ of standardized production area reflects state of its production base and application of science and technology. Management ability is reflected by education background of management personnel. The more technician there, more positive for improvement of cooperative for time being and future. As to social impact, Jiarong Zhao (2009) explained it from contribution made to social economy and public service. From my point of view, social impact is a reflection of contribution to society and could be analyzed through perspectives from government, non-members and members. Policy support from government covers about 10 aspects including standard production norm, marketing and guidance. Service for non-members includes 4 stages, pre-production, mid of production, after production and logistics. All above information obtained by survey would be processed under guidance of expert. With respect to ecological impact, Jinmin Shi (2010) defined environment index by asking whether were certified pollution-free food, ratio of low poison and low pollution agricultural inputs by cooperative members. Ecological impact shows the performance of what cooperative has done for environment. One could examine the impact by asking the certification passed. I used 3 different indicators with different weights in this thesis but scoring method was similar with those before mentioned. Performance Indicater of Farmer's Cooperative is stated as attachment Table 1.

\subsection{Mathematical model}

This thesis adopted 1 9 scale method and judgment matrix and its weight was determined by expert scoring to define comparable importance in between each indicator. According to theorem of AHP, judgment matrix was made, single order and check of consistency also was done.

I used sum product method to calculate its maximum eigenvector and normalized all elements of columns in judgment matrix. Then by adding up all elements of rows in that matrix, approximate solution of the eigenvector was obtained. Finally, from coincident indicator of the judgment matrix, C.I $=* \max -\mathrm{n} / \mathrm{n}-1=0.000631$, random conformance rate (C.R.) $=0.000564<0.1$, we could tell its consistency was acceptable.

With the same method, we reached conclusion about elements of management mechanism, organization income, development potential, social impact and ecological impact that all of whose judgment matrix and single order sequencing had passed consistency test.

$\mathrm{W} 1=(0.29,0.57,0.14) ; \mathrm{W} 2=(0.27,0.4,0.13,0.13,0.07) ; \mathrm{W} 3=(0.29,0.42,0.29) ; \mathrm{W} 4=(0.33,0.22,0.45) ; \mathrm{W} 5=$ $(0.11,0.33,0.56)$. Results of Sequencing are stated as attachment Table 2.

\section{Empirical study}

\subsection{Source of data}

We took sample mainly from Chengdu, Meishan and Ziyang in Sichuan province. In total, there were 142 cooperatives in our sample from 9 counties and districts, namely Dujiangyan, Pengzhou, Shuangliu, Longquan, Pengshan, Renshou, Dongpo, Anyue, Yanjiang. 


\subsubsection{Descriptive statistics analysis}

Descriptive Statistics Analysis is as attachment Table 3.

There five levels can be used for classification. Average value of cooperatives is in the third level, the average profit is in the fifth level, the members stimulated is in the third level, the proportion of sales for their members is in the fifth level. In Sichuan Province, the samples have higher level than others because development of that improves the land concentration and famer's income; it improves the ability of competitiveness in agricultural products. However, in Sichuan, the cooperatives are built later than other Province. Lack of technical personnel and certification, the lower brand seems that agricultural standardization is needed seriously.

\subsubsection{Sample dimensionless processing}

Linear planning is used to have cooperative index numerical value dimensionless disposed, making its value between 0 and 1 . Linear regulation is to transform multi targets into single targets which can measure system quality in general, so as to make comparative analysis easier. However, in above index system, various indexes can't be compared due to different dimensions and functions.

$Y_{i j}$--Dimensionless Value, $X_{i j}$--Actual Value.

$$
Y_{i j}=\frac{X_{i j}}{\sum_{i=1}^{n} X_{i j}}(n=4)
$$

4.2 Empirical analysis

\subsubsection{Cooperative performance and general benefit coordination degree}

Firstly, performance appraisal of every cooperative is evaluated according to the analytic hierarchy process, the formula and variables as following:

$$
V_{j=} \sum_{i=1}^{n} W_{i} Y_{i j}
$$

$\mathrm{V}$ means the general evaluation of professional cooperative, $\mathrm{W}$ means relative index's weight, $\mathrm{Y}$ means evaluation of estimate of every cooperative(Already had dimensionless disposed), i means 5 relative index's weights from 1-5, j means 142 professional cooperatives.

Secondly, the general benefit coordination degree is calculated, to judge the system of governance, the developing of organization, economy, society, ecosystem, whether the performances of such five match up, whether have synchronous development or not. Calculating formula is

$$
I_{C D=} I_{B \min } / I_{B \max } .
$$

\subsubsection{Analysis}

The research of performance evaluation on the specialized cooperative organizations of farmers is stated attachment as Table 4.

Fruit, vegetables cooperatives in large scale, the development of the cooperative in Meishan city are very well. The gap between the cooperatives is larger in Sichuan province. On the whole it is still at the primary stage. Non-standard management, uncoordinated developing, the sustainable development need to be raised.

\section{Measures for promoting the cooperatives` good development}

In order to further perfect the mechanism system, solve problems and improve the performance of the farmers' professional cooperatives in Sichuan province, and promote the healthy development of the cooperative, three suggestions about policy, technology, and talent as following:

\subsection{Policy, to improve the cooperatives ' general competitiveness}

Disseminate "specialized cooperative organizations of farmers Law of P. R.", to survey their business and development regularly, to make good-working cooperatives model with awards and to promote its attractions. For example, the other cooperatives can seriously study Meishan Farmers' Professional Cooperatives` policies visit the demonstration projects for learning experience. Local governments can give different policies and supporting measures according to different development stages of the different cooperatives, to strengthen 
financial capital and credit support, and enhance the general competitiveness of the cooperatives continuously.

\subsection{Technology, to enhance the competitiveness of the cooperatives}

The agriculture standardized production should be extended by the government, to guide the cooperatives to make it executed. People sent by the government specially assigned for a job to supervise the applying of the technology, to improve the technology in cooperatives. To develop dominant industry actively, to expand the scope of fruit planted in the hilly area and increase the planting areas of vegetables, rice planting, Chinese traditional medicine, for using geographic advantages.

\subsection{Talents, to make inner system better}

To focus on talent cultivation and team building, the cooperatives should make good situations to attract graduates from agricultural colleges to work for the cooperatives, let everyone could be there where they need to be. To invite professors from universities, technological specialists to take part in the communication in the cooperatives and study during tours outside, to form good scientific atmosphere, improve the internal management and supervision mechanism, strengthen the cooperative scale, solve the employment problem of farmers. Establish a sales office, actively explore the market, establish the patency of production and marketing channel, perfecting the supervision and management system, and provides the agricultural product tracking service.

\section{References}

CHEN Jiali, \& LI Xuejian. (2011). A Study on Assessment for Bank Performance via PCA and AHP. Chinese journal of systems science, 2, 74-76. [Online] Available: http://dlib.edu.cnki.net/kns50/detail.aspx?dbname=CJFD2011\&filename=XTBZ201101025

CHENG Kequn, \& MENG Lingjie. (2011). Performance evaluation index system construction on Farmer Specialized Cooperatives. Inquiry into Economic Issues, 3, 70-75. [Online] Available: http://dlib.cnki.net/kns50/detail.aspx?QueryID=565\&CurRec=1

GAO Feijin, LIU Huilin, \& ZHAO Jiarong. (2010). Performance evaluation on the specialized cooperative organizations of farmers in Liu Yang. CO-Operative Economy \& Science, 7, 11-19. [Online] Available: http://dlib.cnki.net/kns50/detail.aspx?QueryID=361\&CurRec=1

GONG Mingcong, \& Qin Guozhe. (2011). Discussing of establishing the financial expenditure performance evaluation system. Review of Economic Research, 59, 30-36. [Online] Available: http://dlib.edu.cnki.net/kns50/detail.aspx?dbname=CJFDTEMP\&filename=JJCK201159006

HUANG Xichuan. (1993). About a Method of Evaluating the Scientific Research Achievements of the Scientific Researchers. Journal of Nanjing University Science and Technology (University of Science and Technolog, 6, 81-86. [Online] Available: http://dlib.edu.cnki.net/kns50/detail.aspx?dbname=CJFD1993\&filename=NJLG199306017

HUANG Zuhui, \& ZHAO Ke. (2010). Farmer Specialization Cooperatives: Organizational Structure and Operational Performance in the View of Product Attribute. Academic Exchange, 7, 91-96. [Online] Available: http://dlib.cnki.net/kns50/detail.aspx?QueryID=479\&CurRec=1

HOU Xiang. (2010). Performance evaluation index system on Farmer Specialized Cooperatives: Theory and empirical analysis. Master Dissertation of Shandong university. [Online] Available: http://dlib.edu.cnki.net/kns50/detail.aspx?QueryID=3\&CurRec=1

LIU Bin, CHEN Chibo, and Du hui. (2009). The Positive Analysis of Performance Evaluation on Farmers Co-operative: The Data from 22 Samples Farmer s Co-operative in Jiangxi Province. Issues in Agricultural Economy ,2, 90-95. [Online] Available: http://dlib.cnki.net/kns50/detail.aspx?QueryID=332\&CurRec=9

LU Xiao-xu, LU Yu-qi, \& GU Dao-hong. (2011). A Study of Performance Evaluation of Teachers and Allocation of Wages in the Compulsory Education Based on the Analytic Hierarchy Process. Theory and Practice of Education, 3, 30-34. [Online] Available: http://dlib.edu.cnki.net/kns50/detail.aspx?dbname=CJFD2011\&filename=JYLL201107009

LUO Xiaochun, \& LU lin. (2011). Performance evaluation index system on the third party logistics enterprise logistics service Based on AHP. Communication of Finance and Accounting, 4, 45-46. [Online] Available: http://dlib.edu.cnki.net/kns50/detail.aspx?dbname=CJFD2011\&filename $=$ CKTX201111025

LI Xiaowei, PIAO Yinyue, YIN Shaohua, \& ZHANG Huaiyun. (2011). Study of the performance of Hunan meat enterprise based on the analytic hierarchy process. Journal of Central South University of Forestry \& Technology, 
4, 200-204. [Online] Available:

http://dib.edu.cnki.net/kns50/detail.aspx?dbname=CJFD2011\&filename=ZNLB201104040

LI Lei, DING Haoguo, GAO Fengwei, XIA Heng, \& GANG Yang. (2011). Study on Performance Evaluation System of High-Performance Knowledge Workers in Public Institutions - Based on the Example of the University Teachers. Studies in Philosophy of Science and Technology, 12, 107-112. [Online] Available: http://dib.edu.cnki.net/kns50/detail.aspx?dbname=CJFDTEMP\&filename=KXBZ201106021

Nie, Yonggang, \& Linlin. (2011). Application AHP in the enterprise environment cost decision management. Friends of Accounting, 6, 36-38. $\quad$ [Online] Available: http://dlib.edu.cnki.net/kns50/detail.aspx?dbname $=$ CJFD2011\&filename $=$ KJZY201127010

PAN Keding. (2010). The Research of operation performance and influence factor on Farmers' professional co-operatives. Master Dissertation of Yangzhou university. [Online] Available: http://dib.cnki.net/kns50/detail.aspx?QueryID=881\&CurRec=1

QIAN Mingxia, JIN Zhongkun, \& LIU Song. (2011). Research on Evaluation System of Regional Cultural Industry Competitiveness Based on ANP. Science and Technology Management Research, 17, 71-74. [Online] Available: http://dlib.edu.cnki.net/kns50/detail.aspx?dbname=CJFD2011\&filename=KJGL201117020

RESEARCH Group in Department of Agriculture of Zhejiang Province. (2008). Performance evaluation index system first exploration on Farmer Specialized Cooperatives. Management and Administration on Rural Cooperative, 10, 31-35. [Online] Available: http://dlib.cnki.net/kns50/detail.aspx?QueryID=648\&CurRec $=1$

REN Chunyan. (2011). Zhifanggou Valley Agricultural Eco-economic System Benefit Evaluation Based on Analytic Hierarchy Process. Research of Soil and Water Conservation, 8, 214-218. [Online] Available: http://dib.edu.cnki.net/kns50/detail.aspx?dbname=CJFD2011\&filename=STBY201104047

SHI Jinmin. (2010). The research of performance evaluation on Farmer Specialized Cooperatives. Master Dissertation of Northwest forestry university. [Online] Available: http://dib.cnki.net/kns50/detail.aspx?QueryID=974\&CurRec=3

WILLARTLEY. (2001). Establishing an Integrated performance Measurement system. The Performance Based Management Handbook, A Six Volume ComPilation Of Techniques and Tools for ImPlementing the Government Performance and Results Act of 1993, volume 2, 9.

WANG Liping, ZHANG La, HUANG Zhangbing. (2008). The research of performance evaluation on the specialized cooperative organizations of farmers. Rural Economy, 3, 124-126. [Online] Available: http://dib.cnki.net/kns50/detail.aspx?QueryID=189\&CurRec=1

WU Xu, WANG Xuben, KAN Aike, PENG Peihao, \& CHEN Wende. (2011). Watershed ecological assessment system of decision-making based on AHP method. Journal of Chengdu University of Technology (Science \& Technology Edition), $\quad$ 4, 126-131. Anline] Avalable: http://lib.edu.cnki.net/kns50/detail.aspx?dbname=CJFD2011\&filename=CDLG201102004

WANG Xueliang, \& LI Jianyi. (2011). Study on indexes system for assessing debris flow risk based on AHP. China Mining Magazine, 10, 113-117. [Online] Available: http://dib.edu.cnki.net/kns50/detail.aspx?dbname=CJFD2011\&filename=ZGKA201110029

WANG Fang, \& GUO Jianchun. (2011). Study on Performance Evaluation of Banana Cooperatives. Journal of Tropical Organisms, 11. [Online] Available: http://dlib.cnki.net/kns50/detail.aspx?QueryID=707\&CurRec=1

YANG Yitan. (2005). An Analysis of the Efficiency of the Rural Specialized Productive Cooperation System. Master Dissertation of Zhejiang University. [Online] Available: http://dlib.cnki.net/kns50/detail.aspx?QueryID=763\&CurRec=1

XU Xuchu. (2009). Performance evaluation index system and verification on Farmer Specialized Cooperatives. Journal of Agrotechnical Economics, 411-19. [Online] Available: http://dlib.cnki.net/kns50/detail.aspx?QueryID=275\&CurRec=1

Zhao Hongli, \& Chen Xiuwen. (1993). Policy analysis on Chaidamu areas of qinghai province about land and comprehensive development planning. Journal of Qinghai Environment, 3, 25-30. [Online] Available: http://dlib.edu.cnki.net/kns50/detail.aspx?dbname=CJFD1993\&filename=QHHJ199301005

ZHANG Bing, YU Shengguo, \& MENG Defeng. (2008). Performance evaluation on the specialized cooperative organizations of farmers in Northern Jiangsu Area. Journal of Fujian Agriculture and Forestry University (Philosophy and Social Sciences), 11, 50-53. [Online] Available: 
http://dlib.cnki.net/kns50/detail.aspx?QueryID=103\&CurRec=1

ZHANG Peng, Kong Youshu, \& SUI Shijiang. (2010). The course of development and the Suggestions of policy for specialized cooperative organizations of farmers in China. Agricultural economy, 11, 40-41. [Online] Available: http://dlib.cnki.net/kns50/detail.aspx?QueryID=393\&CurRec=1

http://doc.mbalib.com/view/1b3db45091188c14d6dc81584c04df9f.html

http://www.scaic.gov.cn/zwdt/zwxw/201108/t20110808_98444.html

Table 1. Performance indicater of farmer's cooperative

\begin{tabular}{|c|c|c|c|}
\hline $\begin{array}{l}\text { First Class } \\
\text { Indicator }\end{array}$ & $\begin{array}{l}\text { Second Class } \\
\text { Indicator }\end{array}$ & Third Class Indicator & Description \\
\hline \multirow{17}{*}{$\begin{array}{l}\text { Perfomance } \\
\text { Indicater on } \\
\text { the specialized } \\
\text { cooperative } \\
\text { organizations } \\
\text { of farmers } \\
\text { A1 }\end{array}$} & \multirow{3}{*}{$\begin{array}{l}\text { Management } \\
\text { Mechanism } \\
\text { B1 }\end{array}$} & $\begin{array}{l}\text { Number of Members } \\
\mathrm{C} 1\end{array}$ & $\begin{array}{l}\text { A:0 99;B:100 200;C:201 1000;D:1001 200 } \\
0 ; \mathrm{E}: \text { Above } 2000\end{array}$ \\
\hline & & Level of cooperative $\mathrm{C} 2$ & $\begin{array}{l}\text { A: Town; B: County; C: Municipal; D: } \\
\text { Provincial; E: National; }\end{array}$ \\
\hline & & $\begin{array}{l}\text { whether are personnel } \\
\text { designated to monitor } \\
\text { the quality of farmer's } \\
\text { business C3 }\end{array}$ & A: Yes; B: No. \\
\hline & \multirow{5}{*}{$\begin{array}{l}\text { Organization } \\
\text { Income } \\
\text { B2 }\end{array}$} & $\begin{array}{l}\text { Annual Income } \\
\text { (Unit:10 thousand) } \mathrm{C} 4\end{array}$ & $\begin{array}{l}\text { A:Below200;B:200 800;C:801 1500;D:1501 } \\
\sim 3000 ; E: \text { Above 300 }\end{array}$ \\
\hline & & $\begin{array}{l}\text { Profit and Loss } \\
\text { (Unit:10 thousand) C5 }\end{array}$ & $\begin{array}{l}\text { A:Below10;B:10 30;C:31 90;D:91 270;E:A } \\
\text { bove } 270\end{array}$ \\
\hline & & $\begin{array}{l}\text { Ratio Between } \\
\text { Agricultural Food Sales } \\
\text { Volume From } \\
\text { Cooperative Members } \\
\text { and Total Sales Volume } \\
\text { (\%) C6 }\end{array}$ & $\begin{array}{l}\text { A:Below20;B:20 40;C:40 60;D:60 80;E:80 } \\
100\end{array}$ \\
\hline & & $\begin{array}{l}\text { Member's Satisfaction } \\
\text { C7 (Inquiry from } \\
\text { Farmer) }\end{array}$ & $\begin{array}{l}\text { A: Very unsatisfied }=1 ; B: \text { Quite unsatisfied }=2 \\
\text { C: Satisfied }=3 ; D: \text { Quite Satisfied=4;E:Very } \\
\text { satisfied }=5\end{array}$ \\
\hline & & Brand Awareness C8 & Yes; No \\
\hline & \multirow{3}{*}{$\begin{array}{l}\text { Development } \\
\text { Potential } \\
\text { B3 }\end{array}$} & $\begin{array}{l}\text { Standardized } \\
\text { Production Area C9 }\end{array}$ & $\begin{array}{l}\text { A:0;B:1 200;C:201 1000;D:1001 3000;E:A } \\
\text { bove } 3000\end{array}$ \\
\hline & & $\begin{array}{l}\text { Education Background } \\
\text { of Management Staff } \\
\text { C10 }\end{array}$ & $\begin{array}{l}\text { A: Primary school or below; B: Junior high } \\
\text { school; C: Senior high school or Technical } \\
\text { Secondary School; D: Junior college; E: } \\
\text { College or above. Higher level of education } \\
\text { may lead to better quality of management. }\end{array}$ \\
\hline & & $\begin{array}{l}\text { Number of Technician } \\
\text { C11 }\end{array}$ & $\begin{array}{l}\text { A:0 4; B:5 8; C:9 15; D:16 20; E: Above } \\
\text { 20. More technician may bring more } \\
\text { application of science and technology. }\end{array}$ \\
\hline & \multirow{3}{*}{$\begin{array}{l}\text { Social Impact } \\
\text { B4 }\end{array}$} & $\begin{array}{l}\text { Support from Local } \\
\text { Government C12 }\end{array}$ & $\begin{array}{l}\text { A: Rare ; B:A little ; C: Natural; D: Big; E: } \\
\text { Huge }\end{array}$ \\
\hline & & $\begin{array}{l}\text { Service for } \\
\text { Non-members C13 }\end{array}$ & $\begin{array}{l}\text { A: Rare; B:A little; C: Natural; D: Big; E: } \\
\text { Huge }\end{array}$ \\
\hline & & Annual Training C14 & $\begin{array}{l}\text { A: Rare; B: Occasionally; C: Natural; D: } \\
\text { Often; E: Frequent }\end{array}$ \\
\hline & \multirow[t]{3}{*}{$\begin{array}{l}\text { Ecological } \\
\text { Impact B5 }\end{array}$} & $\begin{array}{l}\text { Green Agricultural } \\
\text { Product Certification } \\
\text { C15 }\end{array}$ & Yes. No. \\
\hline & & $\begin{array}{l}\text { Non-pollution } \\
\text { Agricultural Product } \\
\text { Certification C16 }\end{array}$ & Yes. No. \\
\hline & & $\begin{array}{l}\text { Organic Agricultural } \\
\text { Product C17 }\end{array}$ & Yes. No. \\
\hline
\end{tabular}

Note: The scoring of Qualitative indicators is calculated as 1,2,3,4,5. 
Table 2. Results of sequencing

\begin{tabular}{|c|c|c|c|c|c|}
\hline Indicator & Weight(W) & Hierarchy & Indicator & Weight(W) & Hierarchy \\
\hline C1 & 0.0174 & 15 & C10 & 0.1008 & 3 \\
\hline C2 & 0.0342 & 13 & C11 & 0.0696 & 5 \\
\hline C3 & 0.0084 & 17 & C12 & 0.0560 & 8 \\
\hline C4 & 0.1107 & 2 & C13 & 0.0373 & 12 \\
\hline C5 & 0.164 & 1 & C14 & 0.0747 & 4 \\
\hline C6 & 0.0533 & 9 & C15 & 0.0132 & 16 \\
\hline C7 & 0.0533 & 9 & C16 & 0.0396 & 11 \\
\hline C8 & 0.0287 & 14 & C17 & 0.0672 & 7 \\
\hline C9 & 0.0696 & 5 & & & \\
\hline
\end{tabular}

From table 2, it is observed that Profit and Loss C5 (10 thousands RMB), Annual Income C4 (10 thousands RMB), Education Background of Management Personnel C10 are ranking top 3. It shows the importance of economic and development potential indicator when comes to evaluate its performance. Same in reality, the purpose of joining cooperative is to reduce the risk of sale so as to improve income and high quality management personnel can promote its development and competitiveness to get better gains. 
Table 3. Descriptive statistics analysis

\begin{tabular}{|c|c|c|c|c|c|c|c|}
\hline $\begin{array}{l}\text { Statistical } \\
\text { Indicator }\end{array}$ & $\begin{array}{l}\text { Classification } \\
\text { of Indicator }\end{array}$ & $\begin{array}{l}\text { Number of } \\
\text { Cooperatives }\end{array}$ & $\begin{array}{l}\text { Ratio } \\
(\%)\end{array}$ & $\begin{array}{l}\text { Statistical } \\
\text { Indicator }\end{array}$ & $\begin{array}{l}\text { Classification of } \\
\text { Indicator }\end{array}$ & $\begin{array}{l}\text { Number of } \\
\text { Cooperatives }\end{array}$ & $\begin{array}{l}\text { Ratio } \\
(\%)\end{array}$ \\
\hline \multirow[t]{4}{*}{$\begin{array}{l}\text { Time after } \\
\text { establishment }\end{array}$} & $\begin{array}{l}\text { 1year or } \\
\text { below }\end{array}$ & 26 & 18.3 & \multirow[t]{2}{*}{$\begin{array}{l}\text { Number of } \\
\text { Authentication }\end{array}$} & 0 & 55 & 38.7 \\
\hline & 2 years & 36 & 25.4 & & 1 or above & 87 & 61.3 \\
\hline & 3 years & 37 & 26.1 & \multirow[t]{2}{*}{ Brand owned } & YES & 81 & 57 \\
\hline & $\begin{array}{c}4 \text { years or } \\
\text { above }\end{array}$ & 43 & 30.2 & & No & 61 & 43 \\
\hline \multirow{3}{*}{$\begin{array}{l}\text { Cooperative } \\
\text { Level }\end{array}$} & County & 101 & 71.1 & \multirow[t]{2}{*}{ Standardization } & YES & 101 & 71.1 \\
\hline & Municipal & 15 & 10.6 & & No & 41 & 28.9 \\
\hline & Provincial & 26 & 18.3 & \multirow[t]{5}{*}{ Income } & $\begin{array}{c}\text { Below } \\
\text { 200million }\end{array}$ & 49 & 34.5 \\
\hline \multirow[t]{3}{*}{$\begin{array}{l}\text { Cooperative } \\
\text { Typy }\end{array}$} & Fruit & 65 & 45.8 & & $\begin{array}{l}200 \sim 800 \\
\text { million }\end{array}$ & 58 & 40.8 \\
\hline & Vegetable & 51 & 35.9 & & $\begin{array}{l}801 \sim 1500 \\
\text { million }\end{array}$ & 14 & 9.9 \\
\hline & Others & 26 & 18.3 & & $\begin{array}{l}1501 \sim 3000 \\
\text { million }\end{array}$ & 12 & 8.5 \\
\hline \multirow{4}{*}{$\begin{array}{l}\text { Education } \\
\text { Backgrou-nd } \\
\text { of Main } \\
\text { Manage-ment } \\
\text { Personnel }\end{array}$} & $\begin{array}{l}\text { Primary } \\
\text { school or } \\
\text { below, }\end{array}$ & 6 & 4.2 & & $\begin{array}{l}\text { Above } 3000 \\
\text { million }\end{array}$ & 9 & 6.3 \\
\hline & Junior school, & 37 & 26.1 & \multirow[t]{8}{*}{ Profit or loss } & $\begin{array}{c}\text { Below } 0.1 \\
\text { million }\end{array}$ & 23 & 16.2 \\
\hline & $\begin{array}{l}\text { High school } \\
\text { or technical } \\
\text { secondary } \\
\text { school, }\end{array}$ & 69 & 48.6 & & $0.1 \sim 0.3$ million & 27 & 19.0 \\
\hline & $\begin{array}{l}\text { Above junior } \\
\text { college }\end{array}$ & 30 & 21.1 & & $0.31 \sim 0.9$ million & 25 & 17.6 \\
\hline \multirow{5}{*}{$\begin{array}{l}\text { Number Of } \\
\text { Technician }\end{array}$} & $0 \sim 4$ & 62 & 43.7 & & $0.91 \sim 2.7$ million & 27 & 19.0 \\
\hline & $5 \sim 8$ & 32 & 22.5 & & \multirow{4}{*}{$\begin{array}{c}\text { Above } \\
2.7 \text { million }\end{array}$} & \multirow[t]{4}{*}{40} & \multirow[t]{4}{*}{18.2} \\
\hline & $9 \sim 15$ & 26 & 18.3 & & & & \\
\hline & $16 \sim 20$ & 5 & 3.5 & & & & \\
\hline & Above 20 & 17 & 12 & & & & \\
\hline
\end{tabular}

From Table 3, the specialized cooperative organizations of farmers started late than others, There are seven ones established before 2007, only $4.9 \%$, the other 135 are formed between $2007-2010$, accounting for $95.1 \%$. The cooperative level mainly focuses on County (city) cooperatives. According to the industry type classification, fruit and vegetables cooperatives are very common, others scattered planting herbs, forest, nursery stock and flowers on. Education Background of Main Management Personnel most of them have higher education. According to the Obtaining certification, brand and financial indicators, more than half cooperatives had 1-3 certifications; Most of cooperatives appearing at 2010 and 2009 achieved growth in the profit; Most of them are standardized in agricultural production, but some also use the traditional mode; Generally, one cooperative has 883 members on average. an each one owns 5182 acres and 12 workman, the average annual profit is 5739827 yuan, the average total sales is 13222353 yuan, the average annual income of each member achieved at 14974 yuan, the average profit mounts 6500 yuan. 
Table 4. The research of performance evaluation on the specialized cooperative organizations of farmers from top 10 to last 5

\begin{tabular}{|c|c|c|c|c|c|c|c|}
\hline Name & B1 & B2 & B3 & B4 & B5 & evaluation & cooperative \\
\hline $\begin{array}{l}\text { Cao Jia Farmer Specialization } \\
\text { Cooperatives For Fruits In Ren Sou City }\end{array}$ & 0.0008 & 0.0044 & 0.0030 & 0.0016 & 0.0014 & 0.0112 & 0.1818 \\
\hline $\begin{array}{l}\text { HongYing Farmer Specialization } \\
\text { Cooperatives For Fruits In Mei Shan City }\end{array}$ & 0.0008 & 0.0035 & 0.0028 & 0.0022 & 0.0013 & 0.0106 & 0.2286 \\
\hline $\begin{array}{l}\text { Hua Ren Farmer Specialization } \\
\text { Cooperatives For Jujube In Ren Shou } \\
\text { City }\end{array}$ & 0.0009 & 0.0045 & 0.0028 & 0.0014 & 0.0009 & 0.0105 & 0.2000 \\
\hline $\begin{array}{l}\text { Ju Ai Agricultural development } \\
\text { company in Chengdu City }\end{array}$ & 0.0007 & 0.0044 & 0.0021 & 0.0012 & 0.0014 & 0.0098 & 0.1591 \\
\hline $\begin{array}{l}\text { Gui Rong Farmer Specialization } \\
\text { Cooperatives For Fruits In Long Quan Yi } \\
\text { City }\end{array}$ & 0.0009 & 0.0048 & 0.0013 & 0.0017 & 0.0009 & 0.0096 & 0.1875 \\
\hline $\begin{array}{l}\text { JiXin Farmer Specialization } \\
\text { Cooperatives For Vegetables In MeiShan } \\
\text { City }\end{array}$ & 0.0009 & 0.0039 & 0.0026 & 0.0013 & 0.0009 & 0.0096 & 0.2308 \\
\hline $\begin{array}{l}\text { GuoShan Farmer Specialization } \\
\text { Cooperatives For Vegetables In ZiYang } \\
\text { City }\end{array}$ & 0.0008 & 0.0046 & 0.0021 & 0.0014 & 0.0007 & 0.0096 & 0.1522 \\
\hline $\begin{array}{l}\text { Farmer Specialization Cooperatives for } \\
\text { Trees In GongYi Town }\end{array}$ & 0.0005 & 0.0048 & 0.0020 & 0.0013 & 0.0009 & 0.0095 & 0.1042 \\
\hline $\begin{array}{l}\text { YueHui Of Farmer Specialization } \\
\text { Cooperatives For Seeds In Peng Shan } \\
\text { City }\end{array}$ & 0.0005 & 0.0037 & 0.0026 & 0.0018 & 0.0007 & 0.0093 & 0.1351 \\
\hline $\begin{array}{l}\text { TianGong Farmer Specialization } \\
\text { Cooperatives For Capsicum In Yi He } \\
\text { Town }\end{array}$ & 0.0008 & 0.0035 & 0.0030 & 0.0011 & 0.0009 & 0.0093 & 0.2286 \\
\hline $\begin{array}{l}\text { Farmer Specialization Cooperatives For } \\
\text { Chinese Toon In Shuang Liu city }\end{array}$ & 0.0003 & 0.0016 & 0.0013 & 0.0012 & 0.0007 & 0.0051 & 0.1875 \\
\hline $\begin{array}{l}\text { New Farmer Specialization Cooperatives } \\
\text { For Vegetables in MeiShan City }\end{array}$ & 0.0004 & 0.0017 & 0.0011 & 0.0012 & 0.0007 & 0.0051 & 0.2353 \\
\hline $\begin{array}{l}\text { HongYuan Farmer Specialization } \\
\text { Cooperatives For Fruits In Mei Shan City }\end{array}$ & 0.0003 & 0.0018 & 0.0012 & 0.0010 & 0.0007 & 0.0050 & 0.1667 \\
\hline $\begin{array}{l}\text { HongYuan Farmer Specialization } \\
\text { Cooperatives For emon In An Yue City }\end{array}$ & 0.0003 & 0.0018 & 0.0011 & 0.0010 & 0.0007 & 0.0049 & 0.1667 \\
\hline $\begin{array}{l}\text { JingShan Farmer Specialization } \\
\text { Cooperatives For Fruits And Vegetables } \\
\text { In Shuang Liu City }\end{array}$ & 0.0003 & 0.0017 & 0.0013 & 0.0007 & 0.0007 & 0.0047 & 0.1765 \\
\hline
\end{tabular}

From Table 4, the comprehensive performance score of the cooperatives is relatively low and the average comprehensive score is 0.007 . The comprehensive rank focuses on the overall strength; the comprehensive rank of some cooperative is not the highest, but the strength of it in some aspect is very strong. For example, the Nongfa Planting Specialized Cooperative comprehensively ranks eighth, but the first in the economic efficiency and its relative weak is the internal governance mechanism. All the first five are fruit specialized cooperatives; therefore, the fruit industry is the dominant industry of this region, followed by the vegetable industry.

Top Ten compare with Bottom, the former have obvious superiority than the latter. The top ten are all provincial cooperatives, with good system in supervision and administration, also strong economical power, and the brands. The cooperatives ranking bottom are potential competitor, if they enlarge their business scale, and improve their economical power, they could contribute a lot to the local economy.

As to the general benefit coordination degree, the farmers' professional cooperatives are uncoordinated developing. The income of organization, system of governing, ecosystem unbalance badly, they pay too much attention to the income while ignore the others for the short time they founded, developing deficiently, and the policy need to be better. 